\title{
Mortality of a cohort of tin miners 1941-86
}

\author{
J T Hodgson, R D Jones
}

\section{Abstract}

The mortality patterns of United Kingdom tin miners were examined in relation to calendar period and duration of underground work with particular attention to lung cancer and exposure to radon. Subjects were all men who had worked for at least one year between 1941 and 1984 at one of two United Kingdom tin mines and for whom a complete work history could be constructed from mine records. Standardised mortality ratios (SMRs) were calculated using national (England and Wales) rates. The pattern of SMRs in relation to potential explanatory variables was analysed using Poisson regression methods. Mortalities from lung cancer and silicosis (including silicotuberculosis) were significantly raised and showed a significant relation with duration of underground work (mortality from stomach cancer was raised in both underground and surface workers, but not significantly). Excess mortality from silica related disease declined steeply from $35 \%$ among workers first exposed before 1920 to $1 \%$ among those first exposed after 1950. Thirteen surface workers with known exposure to arsenic had high rates of lung and stomach cancer. The SMR for lung cancer showed a consistent pattern in relation to duration of underground exposure, rising from 83 (observed/expected $=8 / 9 \cdot 6$ ) for surface workers (without exposure to arsenic) to $447(15 / 3 \cdot 4)$ for workers with more than 30 years underground exposure. Examination of the SMR for lung cancer by total underground exposure, age, and time since last exposure gave rise to a model for the expression of risk which depends only on total exposure and time since exposure. The fitted model implies that the effect of exposure to radon in a given year has no effect on risk for 10 years, then rapidly rises to a maximum from which the excess risk then declines, halving every 4.3 years. There were no direct measurements of historic radon levels.

Epidemiology and Medical Statistics Unit, Health and Safety Executive, Magdalen House, Stanley Precinct, Bootle, Merseyside L.20 3QZ

J T Hodgson, R D Jones
A conservative estimate based on measurements taken since 1969 by the National Radiological Protection Board and the Mines and Quarries Inspectorate is that the annual dose to an underground worker was about 10 working level months (WLM). Given this assumption, the risk/exposure slope implied by the present data, and the model fitted to it, was somewhat lower than that given in the fourth Committee on the Biological Effects of Ionisation Radiation (BEIR IV) report (about $40 \%$ lower for lifetime exposures). The present data also imply different risks depending on the age at exposure, with relatively higher lifetime risks for exposure at older ages, and relatively lower risks for exposures at younger ages. In conclusion, there was a clear relation between exposure to radon and death from lung cancer. The relative risk of lung cancer due to exposure to radon was not constant in time but declined from about 10 years from the cessation of exposure. The lifetime excess risk of lung cancer implied by these data for 40 years exposure at the current statutory limit of four WLM a year starting at age 20 , was about $8 \%$ (79 excess deaths per 1000 exposed), assuming average smoking habits among the exposed workers. Control of dust concentrations in the mines has substantially reduced-and may have eliminated-direct mortality from silica related disease.

Exposure to radon gas and, more importantly, to its radioactive decay products, collectively known as radon daughters, has been implicated as the cause of excess lung cancer described in several studies of metalliferous miners. ${ }^{1-6}$ In a survey of radon concentrations in British mines, tin mines gave concentrations among the highest recorded. ${ }^{7}$ A mortality study of men recorded on the 1939 population register as tin miners in two mining areas in Cornwall showed clear evidence of excess mortality from lung cancer among underground workers. ${ }^{8}$ That study had no information on its subjects' job histories, and was therefore unable to look for any relation between duration of exposure and excess mortality. The present study was set up in 1983, with the collaboration of two remaining operational mines, to extend the scope of the 1939 register study, and to look for any evidence of changes over time. 


\section{Materials and methods}

STUDY POPULATION AND JOB HISTORIES

The population was drawn from the two remaining operational tin mines in Cornwall (in 1985) using the mines' personnel and pay records. Where details such as forenames or birth dates were missing, local electoral and civil registers were checked. Identification details and job histories were collected for all workers who had at least 12 months mining experience between 1 January 1941 and 1 May 1984, excluding those who were aged over 60 when they started mining work and those with dates of birth earlier than 1880 .

The job histories consisted of start and finish dates for periods of work at the mine. Periods of work were classified into three main categories (underground, surface, and intermediate) depending on the extent of underground exposure. Two further special categories were also distinguished-previous mining experience noted (with dates of duration) in the earliest mine B records, and work in the arsenic calcining plant at mine A. Because of the suspected carcinogenic effect of arsenic, the 13 workers known to have worked on this process were excluded from the main analysis. The treatment of intermediate and previous mining jobs is discussed further below.

Table 1 shows the numbers of workers in different

Table 1 Job histories by mine

\begin{tabular}{lllr}
\hline & \multicolumn{3}{l}{ No of workers } \\
\cline { 2 - 4 } Job history type & Mine $A$ & Mine $B$ & Total \\
\hline $\begin{array}{l}\text { A: At least one definite } \\
\quad \text { underground job, and: }\end{array}$ & & & \\
$\begin{array}{l}\text { no intermediate jobs } \\
\text { previous mining }\end{array}$ & 1181 & 577 & 1758 \\
$\begin{array}{l}\text { other intermediate jobs } \\
\text { B: No definite underground jobs; }\end{array}$ & 163 & 128 & 128 \\
$\quad$ at least one intermediate job & 432 & 30 & 173 \\
C: Only surface jobs & 315 & 161 & 462 \\
D: At least one arsenic job & 13 & - & 13 \\
Total & 2104 & 906 & 3010 \\
\hline
\end{tabular}

categories of job history, with each mine shown separately. The job histories were divided into four groups defined by the presence in the history of underground and intermediate jobs. In group $A$ all workers had had at least one period of definite underground work. This group was subdivided into three history types: those with no intermediate jobs (histories made up of definite underground and surface jobs only, with at least one underground job); those with previous mining and no other intermediate jobs; and those with other mixtures of intermediate jobs. The second group (group B) of job histories comprised those whose only underground exposure (if any) came from an intermediate job. Group C consisted of workers with only definite surface jobs. The fourth group (D) covered job histories including work on the arsenic calcining plant at mine A.

All dates of start of jobs were known, at least to the year. A number of stopping dates were incomplete, missing, or known only within wide limits. For all incomplete dates the midpoint of the range of possible dates was taken. This imputation procedure was applied to $273(5 \%)$ of job periods and affected 179 $(6 \%)$ of subjects.

The total number of cards sent for flagging at the NHS central register was 3082 . Of these 72 could not be traced giving an overall trace rate of $97.6 \%$.

Deaths were coded by the Office of Population Census and Surveys (OPCS) to the International Classification of Diseases (ICD) revision in force at the time of death. As the observation period ran from 1 January 1941 to 31 December 1986, ICD revisions from the 5 th to the 9 th were used. Table 2 displays the code ranges used from each revision to define the causes of death of interest. The structure of the 5th revision dictated the counting of pleural cancer with cancer of the trachea, bronchus, and lung throughout the study period (for brevity, this is referred to as lung cancer in the rest of the text).

National (England and Wales) death rates were

Table 2 Causes of death and ICD codes

\begin{tabular}{|c|c|c|c|c|c|}
\hline \multirow[b]{2}{*}{ Cause } & \multicolumn{5}{|c|}{ Code range(s) for $I C D$ revision } \\
\hline & $5 t h$ & $6 t h$ & $7 t h$ & $8 t h$ & $9 t h$ \\
\hline $\begin{array}{l}\text { Silicotuberculosis } \\
\text { Cancer of: }\end{array}$ & 131 & 10 & 10 & 100 & 144 \\
\hline $\begin{array}{l}\text { stomach } \\
\text { trachea, bronchus, lung, and pleura } \\
\text { Leukaemia } \\
\text { Ischaemic heart disease } \\
\text { Respiratory disease other than }\end{array}$ & $\begin{array}{l}462 \\
472 \\
741 \\
941-942\end{array}$ & $\begin{array}{l}462 \\
162-163 \\
204 \\
4200-4202\end{array}$ & $\begin{array}{l}151 \\
162-163 \\
204 \\
4200-4202\end{array}$ & $\begin{array}{c}151 \\
161-163 \\
204-207 \\
4100-4149\end{array}$ & $\begin{array}{l}151 \\
162-163 \\
204-208 \\
4100-4149\end{array}$ \\
\hline $\begin{array}{l}\text { pneumoconiosis } \\
\text { Silicosis } \\
\text { Accidents, poisoning, and violence }\end{array}$ & $\begin{array}{r}1040-1140 \\
1143-1146 \\
114 \\
1631-1980\end{array}$ & $\begin{array}{c}470-522 \\
5241-5273 \\
5230-5233 \\
8000-9990\end{array}$ & $\begin{array}{c}470-522 \\
5241-5273 \\
5230-5233 \\
8000-9990\end{array}$ & $\begin{array}{l}460-514 \\
5163-5199 \\
515 \\
8000-9990\end{array}$ & $\begin{array}{l}460-499 \\
505-519 \\
500-502,505 \\
8000-9990\end{array}$ \\
\hline Revision first used & 1940 & 1950 & 1958 & 1968 & 1979 \\
\hline
\end{tabular}


used to calculate expected numbers. These were derived from detailed mortality and population data tapes provided by OPCS. Age standardisation was by five year age groups up to age 84 with an open ended group for ages greater than 85 . Standardisation of calendar time was as near as possible by five year periods within the periods of each ICD revision.

Person-years were counted from the day each subject achieved 12 months employment at the mines (or 1 January 1941 if later), up to the earliest of date of death, date of emigration, or 31 December 1986, except for workers at mine $B$ with non-underground jobs between 1941 and 1964 . Because of the way the personnel records for mine B were set up, these workers could only be included on the survey records if they also had an underground spell in this period, or if they were still working in 1965; accordingly time employed before their first underground job or 1 January 1965 (whichever was the earlier) was excluded from the person-years count for the study.

Observed and expected deaths were calculated using the occupational cohort mortality analysis program developed at the University of Pittsburgh. ${ }^{9}$

\section{EXPOSURE ASSESSMENT}

No measurements of underground radon concentrations exist for these mines before those made in 1967 for the National Radiological Protection Board (NRPB) report cited above. ${ }^{7}$ Since that report the NRPB and the Mines and Quarries Inspectorate (MQI) have continued to monitor radon concentrations. In a recent unpublished review of these monitoring data by the NRPB (M O'Riordan, personal communication) it was concluded that, in the period since 1967, the average annual time weighted full shift exposure was likely to have been in the range eight to 12 working level months (WLM) in mine A and nine to 19 WLM in mine B. Extrapolation of this information to earlier periods is a necessarily speculative exercise, but this speculation can be based on a number of qualitative facts. Firstly, it has proved difficult to change radon concentrations in these mines by improvements in ventilation. Both mines, but particularly mine A, consist of a complicated network of interconnected shafts and workings developed over more than 200 years. Changes in ventilation designed to bring more surface air to the active workings can generate flows from other parts of the mine with no net fall in radon concentrations (sometimes increases). It is therefore unlikely that ventilation changes in earlier years, designed solely to improve the temperature or breathability of the workplace air will have led systematically to major changes in radon concentrations. Secondly, in mine $B$, the earliest series of measurements predated a major and ultimately successful effort to reduce radon concentrations. These early measurements suggest that the concentrations in mine $B$ were higher in the years up to 1967 than subsequently. On the basis of these considerations the NRPB paper suggests average concentrations of 10 WLM a year throughout the study period for mine $A$, and 20 WLM a year up to 1970 and 15 WLM after 1970 for mine B.

\section{UNCERTAINTIES IN UNDERGROUND TIME}

Before analysis of the mortality of the population in relation to time spent underground could be performed, some weighting of intermediate job time and previous mining time in relation to definite underground job time had to be decided. There is little information to support any decision about weightings. All previous mining jobs lay well in the past, and although it is likely that most were in Cornish tin mines and underground (since all were subsequently underground men), this is not known for certain. The other intermediate job categories cover job titles of varying degrees of precision about which all that can be said is that they contained some underground time. Taken as a whole their average underground weighting is likely to be nearer zero than $100 \%$, but for some workers the opposite may have been the case.

The choice of a weighting for intermediate job time could be avoided by excluding all men with any job time in these categories, but this would also exclude some men with substantial known underground exposure. In what follows, analyses considering underground exposure exclude all men with intermediate job time but no definite underground time (job history type $B$ in table 1 ). The weighting of intermediate jobs in the histories of those men who also had known underground jobs was chosen by comparing analyses based on different weightings with corresponding analyses of workers with "pure" underground work histories. These comparisons suggested a $50^{\circ} \%$ weighting of prior mining time in relation to definite underground time, and a $25 \%$ weighting of other intermediate jobs.

\section{Results}

Table 3 shows the overall mortality of the whole study population. There was a highly significant excess of deaths from all causes. This was accounted for by a $60^{\circ}{ }_{0}$ excess of lung cancer (38 excess deaths), a $40^{\circ}{ }_{0}$ excess of cancer of the stomach (eight excess deaths), and $40 \%$ excess of accidental deaths (14 excess deaths), 49 deaths from silicosis, and 33 from silicotuberculosis. Death rates for non-malignant respiratory disease other than pneumoconiosis were normal, as were the rates for ischaemic heart disease.

Table 4 shows cause specific mortality in relation to cumulative time underground. Clear positive associations ( $p$ for trend $<0.001$ ) were found for lung cancer, silicosis, and silicotuberculosis. No associa- 
tions for stomach cancer, ischaemic heart disease, or respiratory disease other than silicosis were found. There was a statistically significant deficit of respiratory disease among those with no underground time (three deaths, 10.8 expected). The excess of mortality from leukaemia in the 10-20 years group taken alone approached significance $(p=0.054)$, but if the expected values for longer exposures were included the SMR fell to $283(3 / 1 \cdot 04, p=0 \cdot 13)$. Two

Table 3 Observed/expected $(O / E)$ deaths and SMRs (or ${ }_{o}{ }_{o}$ excess mortality) for total population

\begin{tabular}{|c|c|c|}
\hline Cause of death & $O / E$ & $S M R$ \\
\hline $\begin{array}{l}\text { All causes } \\
\text { Cancer of the stomach } \\
\text { Cancer of trachea, bronchus, lung, } \\
\text { and pleura } \\
\text { Leukaemia } \\
\text { Ischaemic heart disease } \\
\text { Respiratory disease other than } \\
\text { pneumoconiosis } \\
\text { Silicosis } \\
\text { Silicotuberculosis } \\
\text { Accidents, poisoning, and violence }\end{array}$ & $\begin{array}{c}851 / 671 \cdot 8 \\
27 / 19 \cdot 1 \\
105 / 66 \cdot 6 \\
7 / 4 \cdot 0 \\
208 / 193 \cdot 1 \\
82 / 82 \cdot 8 \\
49 \\
33 \\
51 / 36 \cdot 3\end{array}$ & $\begin{array}{l}126 \cdot 7^{\star \star} \\
141 \cdot 0 \\
157 \cdot 7^{\star \star} \\
173 \cdot 0 \\
107 \cdot 7 \\
99 \cdot 1 \\
\left(7 \cdot 3^{\circ} \mathrm{o}\right) \\
\left(4 \cdot 9^{\circ} \mathrm{o}\right) \\
140 \cdot 6^{\star}\end{array}$ \\
\hline
\end{tabular}

of the three cases were of myeloid type (one acute, the other chronic) and the third was a chronic monocytic leukaemia. Setting aside the mortality figures for the three causes with a clear association with time spent underground, mortality from all other causes showed no such association.

Table 5 shows mortality from lung cancer in relation to underground exposure for the two mines separately. In both cases the SMR increased strongly with increasing exposure. The increase was more consistent in the data for mine $A$ than in the data for mine $B$ in which the SMR for five years cumulative exposure $(8 / 3.5=228 \cdot 7)$ was substantially out of line with the trend suggested by the rest of the data.

The general impression given by the data in table 5 is that the excess risk for lung cancer for a given duration of underground exposure was very similar in the two mines. To examine this impression more rigorously and to look at the effect of other explanatory factors statistical models were fitted to the data by Poisson regression methods ${ }^{11}$ with the GLIM program. ${ }^{12}$

Table 6 defines the variables constructed for detailed regression modelling of the SMR for lung

Table 4 SMRs† (observed deaths in parentheses $\ddagger$ ) by cumulative time underground

\begin{tabular}{|c|c|c|c|c|c|c|c|}
\hline \multirow[b]{2}{*}{ Cause } & \multicolumn{6}{|c|}{ Time underground $(y)$} & \multirow{2}{*}{$\begin{array}{l}\text { Test for } \\
\text { linear trend } \\
p \text { Value }\end{array}$} \\
\hline & nil & $<5$ & $5-10$ & $10-20$ & $20-30$ & $>30$ & \\
\hline All causes & $\begin{array}{c}93 \cdot 3 \\
(84)\end{array}$ & $\begin{array}{l}102 \cdot 1 \\
(167)\end{array}$ & $\begin{array}{l}154 \cdot 2^{\star \star} \\
(123)\end{array}$ & $\begin{array}{l}156 \cdot 0^{\star \star} \\
(175)\end{array}$ & $\begin{array}{l}150 \cdot 3^{\star} \\
(77)\end{array}$ & $\begin{array}{l}189 \cdot 0^{\star \star} \\
(55)\end{array}$ & $<0.001$ \\
\hline Stomach cancer & $\begin{array}{l}204 \cdot 1 \\
(5)\end{array}$ & $\begin{array}{l}117 \cdot 3 \\
(5)\end{array}$ & $\begin{array}{l}133 \cdot 9 \\
(3)\end{array}$ & $\begin{array}{l}145 \cdot 2 \\
(5)\end{array}$ & $\begin{array}{l}128.6 \\
(2)\end{array}$ & $\begin{array}{l}224 \cdot 1 \\
(2)\end{array}$ & $>0.5$ \\
\hline Lung cancer & $\begin{array}{l}83.4 \\
(8)\end{array}$ & $\begin{array}{l}91 \cdot 0 \\
(15)\end{array}$ & $\begin{array}{l}171 \cdot 7 \\
(14)\end{array}$ & $\begin{array}{l}176 \cdot 3^{\star} \\
(21)\end{array}$ & $\begin{array}{l}355 \cdot 4^{\star \star} \\
(17)\end{array}$ & $\begin{array}{l}446 \cdot 6^{\star \star} \\
(15)\end{array}$ & $<0.001$ \\
\hline Leukaemia & $\begin{array}{l}177 \cdot 4 \\
(1)\end{array}$ & $\begin{array}{l}84 \cdot 8 \\
(1)\end{array}$ & $\begin{array}{l}381 \cdot 8 \\
(2)\end{array}$ & $\begin{array}{l}469 \cdot 3 \\
(3)\end{array}$ & $(0 \cdot 25)$ & $\overline{(0 \cdot 15)}$ & $>0.5$ \\
\hline \multicolumn{8}{|l|}{ Respiratory disease other } \\
\hline than pneumoconiosis & ${ }_{(3)}^{27 \cdot 8 \star}$ & $\begin{array}{c}92 \cdot 7 \\
(17)\end{array}$ & $\begin{array}{l}186 \cdot 2^{\star} \\
(17)\end{array}$ & $\begin{array}{l}126 \cdot 8^{\star} \\
(18)\end{array}$ & $\begin{array}{l}94 \cdot 2 \\
(7)\end{array}$ & $\begin{array}{l}103 \cdot 7 \\
(4)\end{array}$ & 0.2 \\
\hline Silicotuberculosis & - & ${ }^{0.6^{\circ}}$ (1) & $(6)^{7 \cdot 5^{\circ}}$ & ${ }_{(12)}^{11^{\circ}}$ & $\begin{array}{l}22 \% \\
(11)^{\circ}\end{array}$ & (2) $6.9 \%$ & $<0.001$ \\
\hline Silicosis & - & $\begin{array}{l}3.7^{\circ} \circ \\
(6)\end{array}$ & $\begin{array}{l}10 \% \\
(8)\end{array}$ & $\begin{array}{l}22^{\circ} \% \\
(25)^{\circ}\end{array}$ & $14 \%$ & $(2)^{6.9 \%}$ & $<0.001$ \\
\hline $\begin{array}{l}\text { All causes other than lung } \\
\text { cancer, silico TB and silicosis }\end{array}$ & $\begin{array}{l}94 \cdot 5 \\
(76)\end{array}$ & $\begin{array}{r}98 \cdot 6 \\
(145)\end{array}$ & $\begin{array}{l}132 \cdot 7 \\
(95)\end{array}$ & $\begin{array}{l}116 \cdot 7 \\
(117)\end{array}$ & $\begin{array}{l}90 \cdot 4 \\
(42)\end{array}$ & $\begin{array}{l}139 \cdot 8 \\
(36)\end{array}$ & $0 \cdot 2$ \\
\hline
\end{tabular}

${ }^{\star} \mathrm{p}<0.05 ;{ }^{\star \star} \mathrm{p}<0.01$.

to Excess mortality for silicotuberculosis and silicosis.

†Expected deaths when no observed deaths.

Table 5 SMRs (observed deaths in parentheses) for lung cancer by time from first exposure and mine

\begin{tabular}{|c|c|c|c|c|c|c|c|}
\hline & \multicolumn{6}{|c|}{ Time underground $(y)$} & \multirow[b]{2}{*}{ Total } \\
\hline & nil & $<5$ & $5-10$ & $10-20$ & $20-30$ & $>30$ & \\
\hline $\begin{array}{l}\text { Mine A } \\
\text { Mine B }\end{array}$ & $\begin{array}{l}101 \cdot 0 \\
(7) \\
37 \cdot 6 \\
(1)\end{array}$ & $\begin{array}{l}53.9 \\
(7) \\
228 \cdot 7 \\
(8)\end{array}$ & $\begin{array}{l}223 \cdot 5^{\star} \\
(12) \\
71 \cdot 2 \\
(2)\end{array}$ & $\begin{array}{l}225 \cdot 5^{\star \star} \\
(14) \\
122 \cdot 5 \\
(7)\end{array}$ & $\begin{array}{l}440 \cdot 6^{\star \star} \\
(7) \\
313 \cdot 1^{\star \star} \\
(10)\end{array}$ & $\begin{array}{l}317 \cdot 1 \star \star \\
(3) \\
497 \cdot 4^{\star \star} \\
(12)\end{array}$ & $\begin{array}{l}146 \cdot 9^{\star} \\
(50) \\
197 \cdot 5^{\star \star} \\
(40)\end{array}$ \\
\hline
\end{tabular}

${ }^{\star} p<0.05 ;{ }^{\star \star} p<0.01$. 
cancer in the study population. For each "cell" of person time defined jointly by the levels of the chosen variables, the observed and expected deaths from lung cancer were calculated. The SMR for each cell was modelled as a function of the explanatory variables assuming a Poisson distribution for SMR weighted by the expected deaths ${ }^{10}{ }^{11}$ (see appendix for details).

Table 7 displays the results of these analyses. Dose was the only statistically significant variable. Some difference in dose effects with latency was evident $(p=0 \cdot 13)$. No interaction effects (not all shown in the table) approached significance. Examinations of residuals and the Pearson $\chi^{2}$ statistic indicated a good statistical fit for the simple dose model or the dose.latency model. Figure 1 shows the model predictions and the underlying data points for the dose model. The fitted value at zero dose was $79 \cdot 4$, which corresponded closely with the local male

Table 6 Variable definitions for Poisson regression modelling of SMR for lung cancer

\begin{tabular}{|c|c|c|}
\hline $\begin{array}{l}\text { Variable } \\
\text { name }\end{array}$ & $\begin{array}{l}\text { Factor/ } \\
\text { variate }\end{array}$ & $\begin{array}{l}\text { Variable definition and } \\
\text { units/levels }\end{array}$ \\
\hline Mine & $\begin{array}{l}\text { Factor } \\
\text { Two levels }\end{array}$ & $\begin{array}{l}\text { Mine } \\
\text { mine } A / \text { mine B }\end{array}$ \\
\hline Duration & $\begin{array}{l}\text { Factor } \\
\text { Six levels }\end{array}$ & $\begin{array}{l}\text { Cumulative exposure }(y) \\
\text { nil } /<5 / 5-10 / 10-20 / 20-30 />30\end{array}$ \\
\hline Dose & Variate & $\begin{array}{l}\text { Cumulative dose measured in years } \\
\text { of exposure. Interval midpoints } \\
\text { of duration ( }>30 \text { taken as } 35)\end{array}$ \\
\hline Latency & $\begin{array}{l}\text { Factor } \\
\text { Three levels }\end{array}$ & $\begin{array}{l}\text { Time from first exposure }(y) \\
0-20 / 20-30 />30\end{array}$ \\
\hline Cohort & $\begin{array}{l}\text { Factor } \\
\text { Five levels }\end{array}$ & $\begin{array}{l}\text { Date of first exposure (y) } \\
\text { up to } 1920 / 1921-40 / 1941-50 / \\
1951-61 / 1962+\end{array}$ \\
\hline $\begin{array}{l}\text { Effective } \\
\text { dose }\end{array}$ & Variate & $\begin{array}{l}\text { Dose measure in terms of time } \\
\text { since exposure (see appendix) }\end{array}$ \\
\hline
\end{tabular}

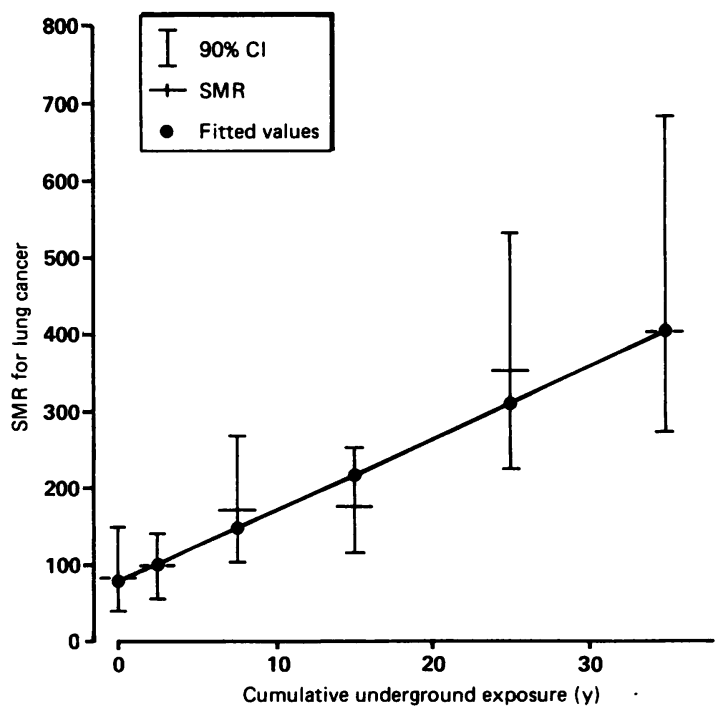

Figure 1 Lung cancer SMR, fitted values and $90 \%$ CI: both mines

SMRs for lung cancer for the period $1968-78,{ }^{13}$ which, excluding the observed and expected numbers from the study population, is $78(95 \%$ confidence interval (CI) 68-88) around mine $A$ and 59 (95\% CI 45-73) around mine B. These results do not suggest any important differences between the two mines, or between the different entry cohorts. The dose response slope for mine A was about $50 \%$ higher than that for mine $\mathrm{B}$, but this difference was not significant.

Although the differences were not statistically significant, the pattern of SMRs by latency is sugges-

Table 7 Poisson regression modelling of SMR for lung cancer: data for combined mines

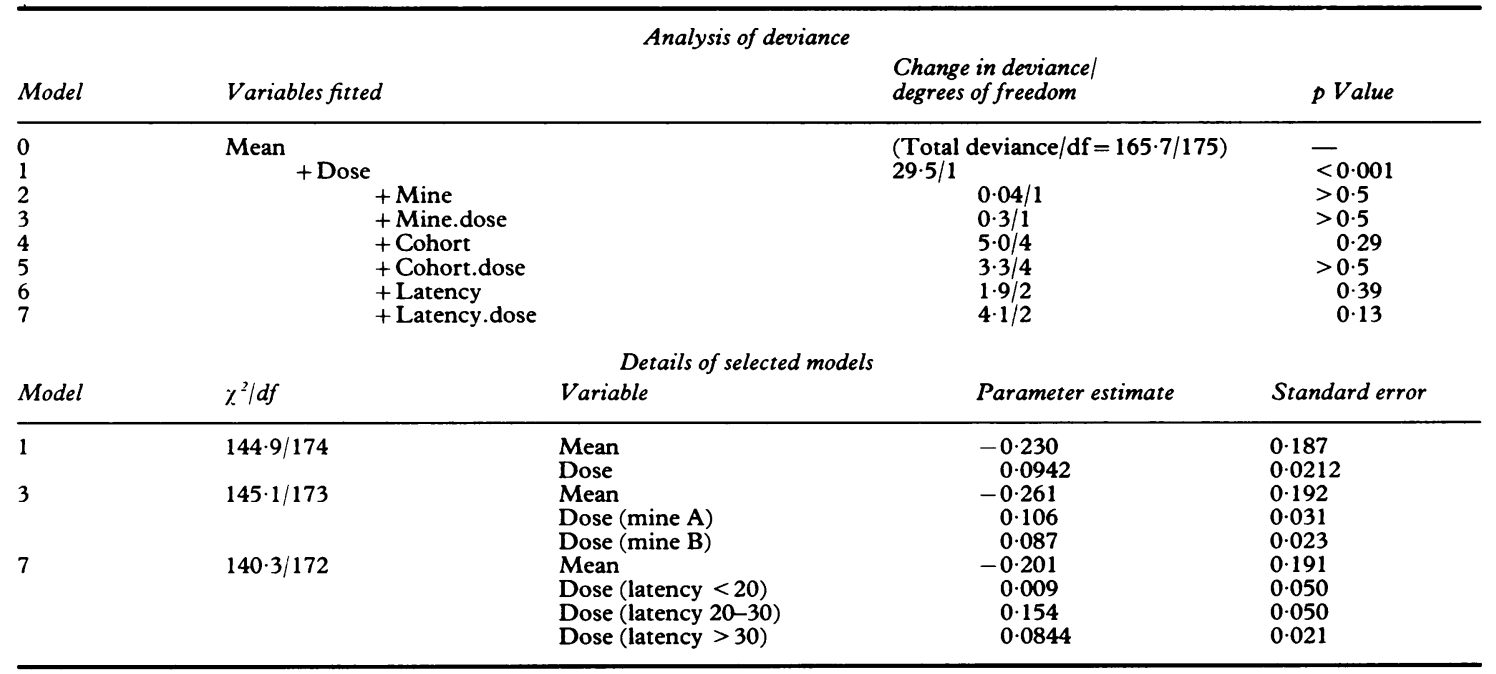


Table 8 SMR for lung cancer (observed deaths in parentheses $\dagger$ ) by total exposure and time since last exposure

\begin{tabular}{|c|c|c|c|c|c|c|}
\hline \multirow[b]{2}{*}{ Total exposure (y) } & \multicolumn{6}{|c|}{ Time since last exposure (y) } \\
\hline & $\begin{array}{l}2 \cdot 5 \\
(0-5)\end{array}$ & $\begin{array}{l}5 \\
(0-10)\end{array}$ & $\begin{array}{l}10 \\
(5-15)\end{array}$ & $\begin{array}{l}15 \\
(10-20)\end{array}$ & $\begin{array}{l}25 \\
(15-35)\end{array}$ & $\begin{array}{l}40 \\
(30-50)\end{array}$ \\
\hline nil & $\begin{array}{l}109 \\
(5)\end{array}$ & $\overline{(1.8)}$ & $\overline{(1 \cdot 2)}$ & 135 & 327 & $\overline{(0.3)}$ \\
\hline$<5$ & 73 & 96 & 159 & 192 & 77 & 69 \\
\hline \multirow[t]{2}{*}{$5-15$} & 101 & 221 & 305 & 177 & $\begin{array}{l}\text { (b) } \\
157\end{array}$ & $\begin{array}{l}(3) \\
150\end{array}$ \\
\hline & (4) & (4) & (5) & (3) & (7) & (3) \\
\hline $15-25$ & $\begin{array}{l}210 \\
(6)\end{array}$ & $\begin{array}{l}342 \\
(4)\end{array}$ & 555 & 303 & $\overline{(10)}$ & . \\
\hline \multirow[t]{2}{*}{$>25$} & 320 & 446 & 728 & - & (1.2) & $\ldots$ \\
\hline & (14) & (5) & (5) & $(0 \cdot 3)$ & & \\
\hline
\end{tabular}

†Expected deaths if no observed deaths.

. Zero person-years in cell.

tive of a path of excess risk that is not constant in time. To examine this question directly table 8 shows the mortality from lung cancer in relation to total exposure and survival time from last exposure. The underlying data for this analysis were derived by dividing the population into subgroups defined by age at last exposure and total years of underground exposure (both in five year groups). Where data were sparse, adjacent exposure categories were combined and the exposure for the combined subgroup was taken as the average of the five year exposure cell mid-points weighted by their person-years. SMR calculations were made separately for each subgroup. Within each subgroup the person-years and expected deaths in the quinquennial age groups younger than the age of the subgroup at last exposure were reallocated to the appropriate age at last exposure subgroup. For example, person-years and expected deaths at ages 25-29 calculated for the subgroup with age 45-49 at last exposure were allocated to the subgroup with age 25-29 at last exposure.

Within each subgroup and quinquennial age group, survival times are defined \pm 5 years $( \pm 2.5$ years if age at last exposure and age fall in the same five year age interval). Subgroups were combined and subgroup $\times$ age group cells with the same survival times and final exposure (nil, <5, 5-15, $15-25,>25$ ) categories were aggregated. The results showed a clear pattern. Within each exposure group the SMR increased with increasing time from final exposure to reach a maximum around 10 years from final exposure. The SMR then declined. The peak SMRs increased with increasing exposure.

The shape of this response suggests an exposure response model in which the effect of a year of exposure increases to a maximum in the following years and then declines. That exposure levels in the study population are thought to have been constant over time (a belief supported by the absence of significant cohort differences), means that modelling the expression in time of the effect of exposure is simplified. To characterise the pattern of risk in time a three parameter model was used in which it is assumed that after a year of exposure there is a period of zero effect, then a period of linearly increasing effect, and finally a period of exponentially decreasing effect. The three parameters determining this pattern are the durations of the periods of zero and of increasing effect and the halving time of the final exponential decrease. We will refer to these parameters as the lag, rising time, and effect half life. In a given year of risk the contributions of previous years' exposures to the current effect are assumed to be additive. We will refer to the total effect as the effective dose. The appendix gives the mathematical details of the model and the calculation of effective dose.

Because this is a non-linear relation, parameter estimates cannot be found analytically. Maximum likelihood estimates of the three parameters were determined by searching over a grid for the values of lag, rising time, and effect half life which optimised

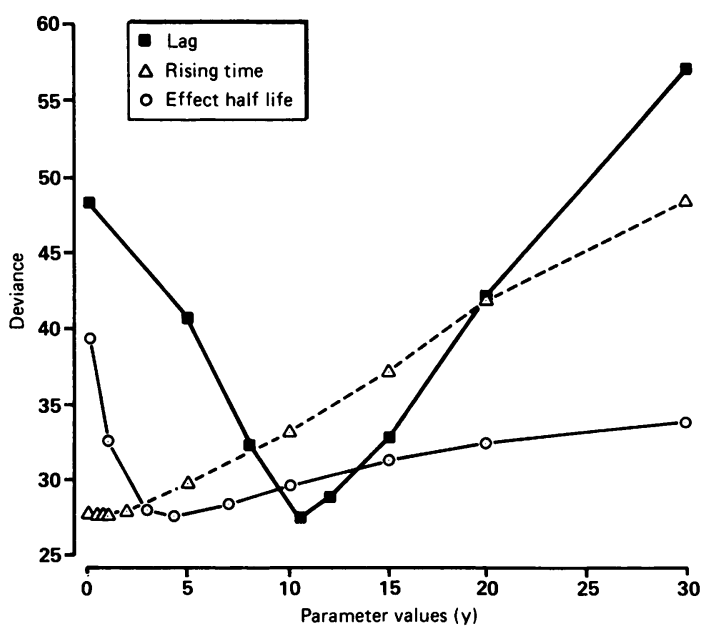

Figure 2 Deviance profiles as a function of lag, rising time, and effect half life 
Table 9 Poisson regression of SMR for lung cancer in terms of effective dose

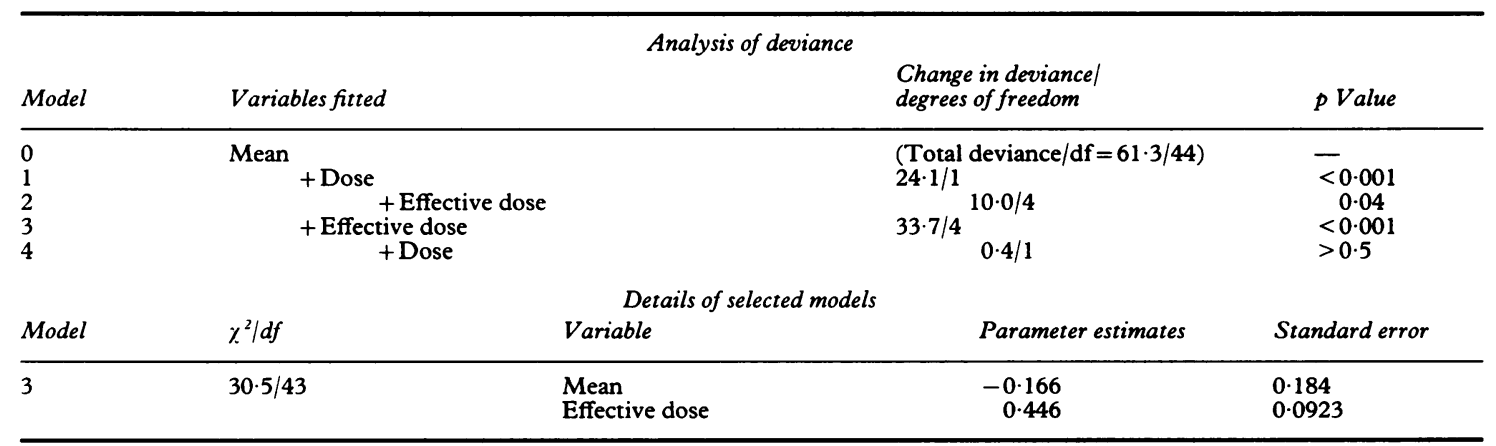

the fit of the effective dose. The best fitting value for the lag was 10.5 years; for the rising time 0.8 years; and for the effect half life 4.3 years. Figure 2 shows the deviance curves around the minimum for each of these three parameters (minimum deviance corresponds to the best fitting value). These curves allow approximate $95 \%$ CIs for the estimates to be calculated. These were 8.3-13.5 for the lag, $0-7 \cdot 8$ for the rising time, and 1.3-15.5 for the effect half life.

Table 9 shows the analysis of deviance for models fitting the effective dose compared with dose unmodified by time since exposure. Although dose on its own gave a highly significant reduction in deviance, effective-dose provided a significant further improvement. When dose was fitted after effective dose the improvement to the fit was not

Table 10 Observed/expected $(O / E)$ lung cancer deaths and $S M R$ for workers known to have worked on arsenic calcining plant

\begin{tabular}{lll}
\hline Cause of death & $O / E$ & $S M R$ \\
\hline All causes & $9 / 7 \cdot 3$ & 124 \\
$\begin{array}{l}\text { Silicotuberculosis } \\
\text { Cancer of the stomach }\end{array}$ & 0 & $(-)$ \\
$\begin{array}{l}\text { Cancer of trachea, bronchus, lung, } \\
\text { and pleura }\end{array}$ & $2 / 0 \cdot 2$ & $890^{\star}$ \\
$\begin{array}{l}\text { Leukaemia } \\
\text { Respiratory disease other than } \\
\text { pneumoconiosis }\end{array}$ & $0 / 0$ & $550^{\star}$ \\
$\begin{array}{l}\text { Silicosis } \\
\text { *p < 0.05. }\end{array}$ & $1 / 1$ & - \\
\hline $\begin{array}{l}\dagger \text { For these three lung cancer deaths, time from first exposure and } \\
\text { years exposure were 14 and 8, 20 and 20, and 23 and 23 years. }\end{array}$
\end{tabular}

significant. In other words effective dose embraced all the explanatory power of dose, and added significantly to it.

\section{MORTALITY OF WORKERS EXPOSED TO ARSENIC}

Arsenic production was an important activity at mine $A$ in the past. The extraction process consisted of heating the ore in brick furnaces to drive off the arsenic as oxide, which was then deposited on the walls of a labyrinthine flue. The flue was periodically opened and the arsenic oxide dug out. In the 1920s several hundreds of tonnes were produced annually. The quantities have fallen steadily and from 1940 to the closure of the calcining plant in 1965, annual production was measured in tens of tonnes. Table 10 shows the mortality data for the 13 workers known to have worked on this process. (They are not included in any other analyses presented). Three deaths from lung cancer occurred compared with an expected number of 0.55 , which was a significant excess $(p=0.02)$, and although the numbers are small, they seem to agree with the general trend that the higher cumulative exposure groups were more at risk from lung cancer. Two of the three workers who died of lung cancer had had 20 or more years of calcining work. It is worth noting that among the workers with arsenic there was a significant excess of deaths from stomach cancer $(p=0 \cdot 2)$.

\section{STOMACH CANCER}

Mortality from stomach cancer was not related to time spent underground (table 4). The whole popula-

Table 11 Observed/expected deaths (SMRs in parentheses) for stomach cancer by mine and total time employed in any tin mining job

\begin{tabular}{|c|c|c|c|c|c|c|c|}
\hline \multirow[b]{2}{*}{ Mine } & \multicolumn{6}{|c|}{ Total cumulative time employed (y) } & \multirow{2}{*}{$\begin{array}{l}\text { p Value } \\
\text { for linear } \\
\text { trend }\end{array}$} \\
\hline & $<5$ & $5-10$ & $10-20$ & $20-30$ & $>30$ & Total & \\
\hline $\begin{array}{l}\text { Mine A } \\
\text { Mine B }\end{array}$ & $\begin{array}{l}6 / 4 \cdot 3 \\
(141) \\
0 / 0 \cdot 8 \\
\end{array}$ & $\begin{array}{l}2 / 2.4 \\
(82) \\
0 / 0.6 \\
-\end{array}$ & $\begin{array}{l}6 / 3 \cdot 1 \\
(192) \\
1 / 1 \cdot 4 \\
(74)\end{array}$ & $\begin{array}{l}3 / 1.9 \\
(157) \\
2 / 1.3 \\
(159)\end{array}$ & $\begin{array}{l}4 / 1 \cdot 7 \\
(238) \\
3 / 1 \cdot 7 \\
(175)\end{array}$ & $\begin{array}{l}21 / 13 \cdot 4 \\
(156) \\
6 / 5 \cdot 7 \\
(105)\end{array}$ & $\begin{array}{l}0.44 \\
0.09\end{array}$ \\
\hline
\end{tabular}


tion, however, showed a $40 \%$ excess of stomach cancer $(p=0 \cdot 1)$. Table 11 shows the SMR for stomach cancer in relation to time employed (whether underground or not). There was some suggestion of increasing SMR with increasing employment in tin mines but the association was not significant ( $\mathrm{p}$ for trend $=0.19$ for data from the mines combined).

\section{SILICOSIS}

Table 12 shows the percentage excess mortality from silicosis and silicotuberculosis (numbers of deaths from these causes as a percentage of expected deaths from all causes, which is also shown in the table), analysed by cumulative time underground and by cohort. For these two causes combined the observed excess mortality fell consistently from cohort to cohort; from $17 \%$ in the pre- 1920 cohort to $2 \%$ in the 1951-61 cohort and zero for 1962 onwards. Silicotuberculosis was confined to the two pre-1940 cohorts.

The information on workers first exposed after 1940 suggests that silicotuberculosis may have been eliminated, and that the incidence of silicosis has been reduced to a half or a third of the pre-1940 levels, possibly lower. The total observed mortality for these cohorts, however, especially in the longer exposure categories, was still low, and the observations were statistically consistent with a wide range of true risk levels for silicosis in these groups. One anomalous feature of the data for mine $A$ is that four of the seven deaths from silicosis among men first exposed after 1940 fell in the less than 5 years underground category. The ages at first employment at the mine for these four men were $38,45,55$, and 57 . The age at first employment of the single case falling in the 1951-61 cohort was 55 .

\section{Discussion}

In outline the pattern of mortality in this population is unsurprising, with a substantial excess of deaths from the known risks of silicosis and lung cancer. For these diseases interest centres on what could be deduced about patterns in relation to presumed exposure levels, and how these compared with

Table 12 Deaths from silicotuberculosis (siTB) and silicosis (sis) as percentage of expected deaths from all causes (exp) by cohort and cumulative time underground

\begin{tabular}{|c|c|c|c|c|c|c|c|}
\hline \multirow[b]{2}{*}{ Cohort } & \multirow[b]{2}{*}{ Disease } & \multicolumn{6}{|c|}{ Cumulative time underground (y) } \\
\hline & & $<5$ & $5-10$ & $10-20$ & $20-30$ & $>30$ & Total \\
\hline-1920 & $\begin{array}{l}\text { SiTB } \\
\text { Sis } \\
\text { Exp }\end{array}$ & $\overline{10} \cdot 6$ & $\begin{array}{l}4^{\circ}{ }_{\circ}(1) \\
8^{\circ} \circ(2) \\
24 \cdot 5\end{array}$ & $\begin{array}{l}15^{\circ} \circ(3) \\
25^{\circ}{ }_{\circ}(5) \\
20 \cdot 1\end{array}$ & $\begin{array}{l}62^{\circ}{ }^{\circ}(10) \\
31^{\circ} \circ(15) \\
16 \cdot 1\end{array}$ & $\begin{array}{l}15^{\circ} \circ(1) \\
15^{\circ} \circ(1) \\
6.5\end{array}$ & $\begin{array}{l}19^{\circ}(15) \\
16^{\circ} \%(13) \\
79 \cdot 8\end{array}$ \\
\hline $1921-40$ & $\begin{array}{l}\text { SiTB } \\
\text { Sis } \\
\text { Exp }\end{array}$ & $\begin{array}{l}1^{\circ} \circ(1) \\
5 \% \circ(4) \\
83 \cdot 7\end{array}$ & $\begin{array}{l}10^{\circ}{ }_{0}(6) \\
10^{\circ}{ }_{0}(6) \\
58.9\end{array}$ & $\begin{array}{l}13^{\circ} \circ(9) \\
24^{\circ} \circ(17) \\
69.9\end{array}$ & $\begin{array}{l}4^{\circ} \circ(1) \\
11^{\circ} \circ(3) \\
28 \cdot 3\end{array}$ & $\frac{5 \%}{20.5}$ & $\begin{array}{l}6 \%(18) \\
11 \%(30) \\
284.4\end{array}$ \\
\hline $1941-50$ & $\begin{array}{l}\text { Sis } \\
\text { Exp }\end{array}$ & $\begin{array}{l}3^{\circ}{ }_{0}(3) \\
110.7\end{array}$ & $\overline{15} \cdot 7$ & $\begin{array}{l}10^{\circ}{ }_{o}(2) \\
20 \cdot 6\end{array}$ & $\overline{5 \cdot 7}$ & $45^{\circ} \circ(1)$ & $4^{\circ}(6)$ \\
\hline $1951-61$ & $\begin{array}{l}\text { Sis } \\
\text { Exp }\end{array}$ & $\begin{array}{l}3 \%(1) \\
34 \cdot 0\end{array}$ & $\overline{9 \cdot 1}$ & $\frac{20 \cdot 0}{9 \cdot 0}$ & $\frac{3 \cdot 7}{2 \cdot 5}$ & $\frac{2 \cdot 2}{0 \cdot 3}$ & $\begin{array}{l}158 \cdot 9 \\
2 \% \circ(1) \\
58 \cdot 3\end{array}$ \\
\hline
\end{tabular}

Table 13 Comparison of lifetime risk estimates based on model fitted to the present data with those based on BEIR model

\begin{tabular}{|c|c|c|c|c|c|c|}
\hline \multirow[b]{2}{*}{$\begin{array}{l}\text { Exposure rate } \\
\text { (WLM a year) }\end{array}$} & \multirow[b]{2}{*}{ From age } & \multirow[b]{2}{*}{ To age } & \multicolumn{3}{|c|}{ Model based on present data } & \multirow{2}{*}{$\begin{array}{l}\text { BEIR } \\
\text { model } \\
\text { relative } \\
\text { lifetime } \\
\text { risk }\end{array}$} \\
\hline & & & $\begin{array}{l}\text { Excess absolute } \\
\text { lifetime risk } \\
\text { per } 1000 \text { exposed }\end{array}$ & $\begin{array}{l}\text { Excess risk } \\
\text { coefficient (deaths) } \\
10^{6} \text { person-WLM) }\end{array}$ & $\begin{array}{l}\text { Relative } \\
\text { lifetime } \\
\text { risk }\end{array}$ & \\
\hline 10 & 35 & $\begin{array}{l}30 \\
40 \\
50 \\
60 \\
45 \\
55 \\
65\end{array}$ & $\begin{array}{r}9 \cdot 6 \\
41 \\
106 \\
183 \\
49 \\
128 \\
192\end{array}$ & $\begin{array}{l}100 \\
200 \\
350 \\
460 \\
490 \\
640 \\
640\end{array}$ & $\begin{array}{l}1 \cdot 11 \\
1.47 \\
2 \cdot 31 \\
3 \cdot 41 \\
1 \cdot 58 \\
2 \cdot 61 \\
3.53\end{array}$ & $\begin{array}{l}1.73 \\
2.47 \\
3.20 \\
3.75 \\
1.82 \\
2.53 \\
2.98\end{array}$ \\
\hline 4 & 35 & $\begin{array}{l}30 \\
40 \\
50 \\
60 \\
45 \\
55 \\
65\end{array}$ & $\begin{array}{l}3 \cdot 9 \\
16 \\
44 \\
79 \\
20 \\
54 \\
84\end{array}$ & $\begin{array}{l}100 \\
200 \\
370 \\
490 \\
500 \\
675 \\
700\end{array}$ & $\begin{array}{l}1.04 \\
1.19 \\
1.51 \\
1.94 \\
1.23 \\
1.63 \\
2.00\end{array}$ & $\begin{array}{l}1.30 \\
1.61 \\
1.94 \\
2.20 \\
1.34 \\
1.64 \\
1.85\end{array}$ \\
\hline $\begin{array}{l}1 \\
0 \cdot 5 \\
0 \cdot 1\end{array}$ & $\begin{array}{l}\text { Lifetime } \\
\text { exposure }\end{array}$ & & $\begin{array}{l}28 \\
14 \\
2 \cdot 8\end{array}$ & $\begin{array}{l}400 \\
400 \\
400\end{array}$ & $\begin{array}{l}1 \cdot 31 \\
1 \cdot 16 \\
1 \cdot 03\end{array}$ & $\begin{array}{l}1 \cdot 51 \\
1 \cdot 26 \\
1 \cdot 05\end{array}$ \\
\hline
\end{tabular}


estimates derived from other populations; and on trends through time. The data for deaths from stomach cancer, leukaemia, and for mortality related to exposure to arsenic also show some features of note.

\section{STOMACH CANCER}

The rates for this cause of death were raised, but not significantly $(p=0 \cdot 1)$. This observation was also made by Fox et al, ${ }^{8}$ who refer to published hypotheses that exposure to dust ${ }^{14-16}$ or physical exertion ${ }^{17}$ may have a role in causing this cancer. The excess in the present study showed no association with work underground, and was not stronger among those employed before 1941 who, as judged by their high levels of silicosis, must have had much the heaviest exposures to dust. As underground work is generally more strenuous than surface work, neither of these hypotheses are supported by the present observations. Stomach cancer shows strong social class differences, with higher rates among manual workers. The local stomach cancer SMR for the period $1968-78,{ }^{11}$ combining the local authority areas containing the mines and excluding the observed and expected deaths in the study population, was 105.7 (79 deaths). Geographical variation does not therefore appear to be a factor.

\section{LEUKAEMIA}

The numbers of deaths from leukaemia (seven, 4.1 expected) were too small to allow detailed analysis, but within this limitation the data are consistent with some raising of rates related to time underground (and hence to doses of radiation). On the basis of published NRPB estimates, ${ }^{18}$ the additional annual whole body penetrating $(\gamma)$ radiation dose received by a miner in either mine would be only about $1 \mathrm{mSv}$. Assuming the recently revised risk coefficients of the Radiation Effects Research Foundation ${ }^{19}$ and a dose rate of $1 \mathrm{mSv} / \mathrm{a}$ year, less than $0 \cdot 1$ additional cases of leukaemia would be expected from the present study population. This compares with an observed excess for non-lymphoid leukaemia of three observed $v 0.7$ expected (one sided $p=0.03$ ) in the greater than 10 years cumulative exposure group. An inconsistency clearly exists. It is difficult to see a plausible biological mechanism by which the much larger radiation doses received in the form of nonpenetrating $\alpha$ radiation from radon and its daughters could reach the bone marrow and cause leukaemia, although it has been suggested that radon dissolved in fat cells could provide a pathway. ${ }^{20}$ Other published studies of radon exposed miners ${ }^{1-68}$ have not reported such excesses, though Swedish iron miners had a non-significant excess of lymphoma. ${ }^{2}$

\section{SILICOSIS AND SILICOTUBERCULOSIS}

The mortality from these two closely related causes has fallen substantially over time, with improvements in control of dust in the mines. The medical control of tuberculosis with the introduction of effective treatment from the late 1940 s will also have played a part and silicotuberculosis can probably be regarded as a historic risk only. Although the mortality from silicosis seen among workers first employed after 1940 was low, and based on few cases, there are two reasons for caution before concluding that the conditions of, say, the 1950s, were free of risk for silicosis. The first reason is that the total mortality of the post 1940 cohort is low, particularly among men with longer exposures, and the ultimate mortality from silicosis may be higher than seen so far. Secondly, not all cases of silicosis will lead to death coded to silicosis as underlying cause, so a mortality analysis such as the present one will predominantly measure the more serious end of the spectrum of silicotic disease. The disappearance of silicosis as a coded cause of death does not imply its disappearance as a cause of disability.

\section{LUNG CANCER}

There was, as expected, a substantial excess of lung cancer strongly related to cumulative time underground. Comparison of successive entry cohorts to the mines suggests that the excess risks have been stable for the first 60 years of the century. As there is a 20 year lag before risks become apparent, the effects of exposures later than 1960 cannot be assessed.

Smoking is the major determinant of mortality from lung cancer, and where the joint effect of smoking and exposure to radon has been studied a multiplicative interaction has been observed. ${ }^{21}$ In a retrospective study of this kind it was not possible to establish the smoking behaviour of the past workforce, and, given the substantial changes in smoking habits that have taken place over the past twenty years the smoking habits of the present workforce could not be used as a proxy measure with any confidence. There is no reason to believe that the study population was exceptional as regards smoking; mortality from ischaemic heart disease, also powerfully influenced by smoking, was normal. The use of age and calendar time specific death rates will, to the extent that the study population does reflect national trends, control for the substantial changes in general smoking habits that have taken place since the 1920 s.

Smoking apart, the main difficulty in the interpretation of these results is the uncertainty about exposure and the inconsistency between the historical assessment of exposure and the observed effects in the two mines. On the basis of the NRPB assessments of exposure, the excess risk in mine B should be about double that in mine $A$. The effect of underground exposure, however, at either mine seems to be similar, and when independent dose 
response slopes were fitted to the data, the slope for mine $\mathbf{B}$ was less than that for mine $\mathbf{A}$. It seems reasonable, therefore, to assume that the average annual dose was the same in the two mines.

What assumption should be made as to the value of this common dose? Our best knowledge about exposures in the two mines relates to the recent past during which the range of measured doses (based on area monitoring) suggests annual doses in the range eight to $12 \mathrm{WLM}$ at mine $\mathrm{A}$ and nine to $19 \mathrm{WLM}$ at mine B. Doses in mine A were fairly consistent over the period 1967-84; doses in mine $B$ were at the higher end of their range in the early part of the period (up to 1973). The consistency found in mine $A$, and the relatively narrow range of estimated annual doses suggests that the estimate of 10 WLM a year here is more soundly based than the extrapolation to 20 WLM a year for mine B. We prefer to choose one or other of the estimated values rather than taking an average because the logic of our position, having decided on the basis of the observed mortality data that the doses received in the two mines were closely similar, is that one of the estimates is wrong. Accordingly we assume a common dose of 10 WLM a year. On this basis the risk model indicated by our analysis of these data is:

$$
\text { Relative risk }=1+0.045 \int_{t_{0}}^{t s} r(t) w(t) d t
$$

where $r(t)$ is the dose rate in WLM a year; $t_{0}$ is the time in years since cessation of exposure $\left(t_{0}=0\right.$ if subject is still exposed); $t_{s}$ is the time since first exposure; and $\mathrm{w}(\mathrm{t})$ is the weighting function formally described in the appendix with $d_{1}=10.5, d_{2}=0.8$, $\mathrm{d}_{3}=4 \cdot 3$. The coefficient 0.045 is the effective dose coefficient in model 3 of table $14(0.4466)$ divided by 10 (the assumed annual dose rate), and rounded. The constant is set aside, as this is taken to represent the fact that the local rates for lung cancer (for men who were not tin miners) were lower than the national rates used in the SMR calculations.

The risks implied by this model are summarised in table 13, which shows the lifetime relative and absolute risk of lung cancer for a range of degree of exposure, durations, and ages of start. These risk figures were calculated by applying our model of relative risk to lung cancer rates for men in England and Wales in 1979-84; a representative population in which $80 \%$ of men are, or have been, regular smokers. The excess risk coefficients vary widely with the age at which exposures are received, being lower for exposures at younger ages. For lifetime exposures the risk averages out at 400 excess deaths per $10^{6}$ person-WLM.

The report of the fourth Committee on the Biological Effects of Ionising Radiation (BEIR) ${ }^{21}$ presents re-analysis of the data from four of the five major radon exposed groups for which analyses have been published. We put our present analysis in the context of the evidence from other populations by a comparison with the model developed by the BEIR committee from those four populations. To make this comparison table 13 gives the relative lifetime risk predicted by the BEIR model along with the corresponding predictions from our model. Overall our model predicts rather lower risks than the BEIR model. For example the relative excesses predicted for lifetime exposures are about $70 \%$ higher on the BEIR model. For doses received at working ages the differences vary depending on the age at exposure. The differences are greatest for short exposures at young ages; the BEIR excess relative risk is seven times our model value for exposure from age 20 to age 30. This difference falls as the period of exposure lengthens into older ages, and for exposures from age 20 to 60 the BEIR excess relative risk is only slightly higher. For exposures starting at older ages the differences are less marked: BEIR $40 \%$ higher for exposure from age 35 to 45; BEIR 30\% lower for exposure from age 35 to 65 .

The differences between the present model and the BEIR model are of two types; the difference in overall risk, and the different treatment of the expression of risk through time. As regards the difference overall, one might look to uncertainties in the estimation of past exposures for an explanation. But within this study the uncertainties relating to the assumed average dose of 10 WLM a year are on the upward side and a revision of this assumption upwards would lead to a greater discrepancy with the BEIR model. Taken individually, the data on the four populations contributing to the BEIR model give rather different risk values with an approximate four fold difference between the lowest (Colorado) and the highest (Saskatchewan). The present study lies within this range.

For the temporal expression of risk, the present data have the advantage of 45 years follow up- 15 years longer than any of the data underlying the BEIR model. On biological grounds it seems more plausible that the pattern of risk should be linked to the time since exposure than that there would be fixed changes in risk at specific ages regardless of how far into the past the exposure responsible for the risk was situated. The difference, however, between the models in this respect should not be overemphasised. All the published data sets on exposure to radon show a decrease in relative risk in the final periods of follow up; what is at issue is the most appropriate way of modelling and interpreting this aspect of the data.

We gratefully acknowledge the invaluable assistance of Dr Joan Davis of the Institute of Cancer Research who was responsible for the exhaustive process of establishing detailed working histories for the subjects of this study. Our thanks also go to the 
management and workers at the mines who gave their full cooperation to our efforts at a time of considerable difficulty for their industry. The tracing and flagging of the population was done with their customary efficiency and helpfulness by staff of the NHS central register. We also thank our own support staff-particularly Anne Fletcher ansd Gwen Leewho were responsible for setting up and maintaining the computer data files, and Madeleine Naylor who did much preparatory computing work. Helpful comments on early drafts of this report were received from Dr Michael O'Riordan, Colin Muirhead, and Darren Dixon of the NRPB and from our Health and Safety Executive colleague Peter Thomas.

\section{Appendix}

LINK FUNCTION FOR POISSON REGRESSION OF SMR

SMRs are necessarily positive, and a sensible statistical SMR model must reflect this property. This means that the relation between an SMR and a set of explanatory variables cannot be a simple linear function (as this will always be negative for some values of the explanatory variables). The mathematically "natural" solution to this difficulty is to define the relationship as:

$$
\mathrm{SMR}=\mathrm{e}^{n}
$$

where $\eta$ is a linear function of the explanatory variables. This mathematically convenient solution, however, has the strong substantive implication that additive increments in the explanatory variables produce multiplicative increases in the SMR. The existing evidence on the dose response relation between radon and lung cancer (including the present data) suggests that this is not the case, and that increments in exposure to radon give additive increases in the SMR (or relative risk): in other words that the correct relationship is of the form

$$
\operatorname{SMR}=\eta
$$

The dilemma can be avoided by observing that we need only insist on the linear relation for values of the SMR around 1 and higher. The form chosen for the relation at very low values of the SMR is of no practical significance as such values do not exist in the real world. The relation must, however, be defined over the whole mathematically possible range of values for the purposes of the fitting algorithm. For the modelling in this paper the relation was defined as follows:

$$
\mathrm{SMR}=\begin{array}{ll}
\mathrm{e}^{\eta} & \text { for } \eta<0 \\
1+\eta & \text { for } \eta \geqslant 0
\end{array}
$$

This gives a linear relation for SMR values of 1 or greater; and a fairly good approximation to a linear relation for SMRs down to about 0.60 , as shown in the following table:

\begin{tabular}{llllll}
\hline$\eta$ & 0 & -0.2 & -0.4 & -0.6 & -0.8 \\
\hline $1+\eta$ & 1.00 & 0.80 & 0.60 & 0.40 & 0.20 \\
$\mathrm{e}^{\eta}$ & 1.00 & 0.81 & 0.67 & 0.55 & 0.45 \\
\hline
\end{tabular}

This link function was programmed as an OWN model in GLIM, assuming a Poisson distribution for the SMR weighted by expected deaths (SMR $\times$ expected deaths = observed deaths), and with the GLIM scale parameter constrained to 1 .

THE RISK IN TIME MODEL

We assumed that a year of underground exposure produces a pattern of effect in the future as follows:

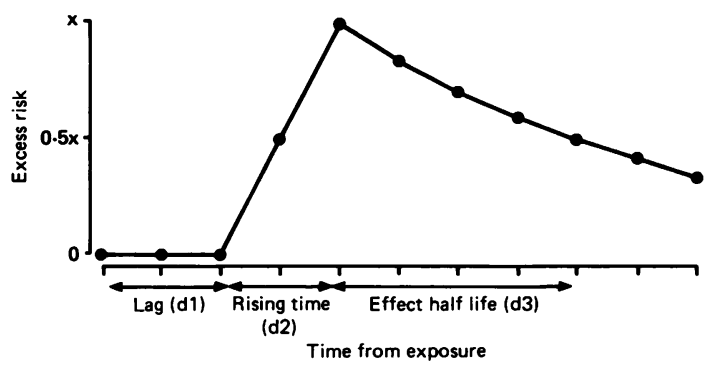

After a period $\left(d_{1}\right)$ of zero effect, the effect increases linearly to a maximum ( $x$ ) over a second period of time $\left(d_{2}\right)$. The effect then declines exponentially, falling to half the maximum value at time $d_{3}$ from the maximum. The maximum effect $(x)$ will be a function of total exposure in the year in question. As exposures of the current population have been taken to be constant over time $x$ can be arbitrarily fixed as 1 .

At a point in time when a worker's exposure (assumed continuous) lies between $t_{0}$ and $t_{1}$ years in the past, the total effect on that worker is given by the integral of the effect curve between times $t_{0}$ and $t_{1}$. These values can be readily derived from the following integral function:

$$
\begin{aligned}
& I(t)=\int_{0}^{t} w(t) d t=\left\{\begin{array}{l}
0 \\
\frac{1}{2}\left(t-d_{1}\right) \\
\frac{1}{2} d_{2}+\left(1-\exp \left\{-\alpha\left(t-d_{1}-d_{2}\right)\right\}\right) / \alpha \\
t<d_{1}
\end{array}\right. \\
& \quad d_{1} \leqslant t<d_{1}+d_{2}
\end{aligned}
$$

where $\alpha=\log 2 / \mathrm{d} 3$.

1 Kunz E, Sevc J, Placek V, Horacek H. Lung cancer in man in relation to different time distribution of radiation exposure. Health Phys 1979;36:699-706.

2 Radford EP, St Clair Renard KG. Lung cancer in Swedish iron miners exposed to low doses of radon daughters. New England Journal of Medicine 1984;310:1485-94. 
3 Muller J. Study of mortality of Ontario miners 1955-1977, Part I. In: Stocker H, ed. Proceedings of the international conference on occupational radiation safety in mining. Vol 1. Toronto: Canadian Nuclear Association, 1984:335-343.

4 Howe GR, Nair RC, Newcombe HB, Miller AB, Abbatt JD. Lung cancer mortality $(1950-1980)$ in relation to radon daughter exposure in a cohort of workers at the Eldorado Beaverlodge uranium mine. J Natl Cancer Inst 1986;77: 357-62.

5 Hornung RW, Meinhardt TJ. Quantitative risk assessment of lung cancer in US uranium miners. Health Phys 1987;52. 417-30.

6 Morrison HI, Semenciw RM, Mao Y, Wigle DT. Cancer mortality among a group of fluorspar miners exposed to Radon progeny. Am J Epidemiol 1988;128:1266-75.

7 Strong JC, Laidlaw AJ, O'Riordan MC. Radon and its daughters in various British mines. Chilton: National Radiological Protection Board, 1975. (NRPB publ No R39.)

8 Fox AJ, Goldblatt P, Kinlen LJ. A study of the mortality of Cornish tin miners. Br J Ind Med 1981;38:7378-80.

9 Marsh GM, Preininger M. OCMAP: A user-oriented occupational cohort mortality analysis program. American Statistician 1980;34:245-6.

10 Berry $G$. The analysis of mortality by the subject-years method. Biometrics 1983;39:173-84.

11 Frome EL, Checkoway H. Use of Poisson regression models in estimating incidence rates and ratios. Am J Epidemiol 1985; 121:309-23.

12 GLIM Working Party. The generalised linear interactive modelling system manual. Oxford: Numerical Algorithms Group, 1985. (Release 3.77.)
13 Medical Research Council environmental epidemiology unit, Southampton University. Lists of mortality by area, site and sex: $1968-78$.

14 Office of Population Censuses and Surveys. Occupational mortality. The Registrar General's decennial supplement for England and Wales 1970-72. London: HMSO, 1978. (Series DS No 1.)

15 Stocks $P$. On the relations between atmospheric pollution in urban-rural localities and mortality from cancer, bronchitis and pneumoconiosis. $\mathrm{Br} J$ Cancer 1960;14:397-418.

16 Jacobsen M. Dust exposure, lung diseases and coal miners mortality. Edinburgh: University of Edinburgh, 1976. (PhD thesis.)

17 Stukonis M, Doll R. Gastric cancer in man and physical activity at work. Int $J$ Cancer 1969;4:248-54.

18 Dixon DW, James AC, Strong JC, Wrixon AD. A review of all sources of exposure to natural radiation in UK mines. In: Stocker H, ed. Proceedings of the international conference on occupational radiation safety in mining. Vol 2. Toronto: Canadian Nuclear Association, 1985:241-7.

19 Preston DL, Pierce DA. The effect of changes in dosimetry on cancer mortality risk estimates in the atomic bomb survivors. Hiroshima, Radiation Effects Research Foundation, 1987. (RERF technical report 9-87.)

20 Henshaw DL, Eatough JP, Richardson RB. Radon as a causative factor in induction of myeloid leukaemia and other cancers. Lancet 1990;335:1008-12.

21 Committee on the biological effects of ionising radiation (BEIR IV). Health risks on radon and other alpha emitters. Washington DC: National Academy Press, 1988.

Accepted 3 April 1990

\section{Vancouver style}

All manuscripts submitted to the $\mathrm{Br} J$ Ind $\mathrm{Med}$ should conform to the uniform requirements for manuscripts submitted to biomedical journals (known as the Vancouver style)

The $\mathrm{Br} J$ Ind Med, together with many other international biomedical journals, has agreed to accept articles prepared in accordance with the Vancouver style. The style (described in full in $\mathrm{Br}$ Med J, 24 February 1979, p 532) is intended to standardise requirements for authors.

References should be numbered consecutively in the order in which they are first mentioned in the text by Arabic numerals above the line on each occasion the reference is cited (Manson ${ }^{1}$ confirmed other reports $\left.{ }^{2-5} \ldots\right)$. In future references to papers submitted to the $\mathrm{Br} J$ Ind Med should include: the names of all authors if there are six or less or, if there are more, the first three followed by et al; the title of journal articles or book chapters; the titles of journals abbreviated according to the style of Index Medicus; and the first and final page numbers of the article or chapter.

Examples of common forms of references are:

I International Steering Committee of Medical Editors. Uniform requirements for manuscripts submitted to biomedical journals. Br Med J 1979;1:532-5.

2 Soter NA, Wasserman SI, Austen KF. Cold urticaria: release into the circulation of histamine and eosino-phil chemotactic factor of anaphylaxis during cold challenge. $N$ Engl J Med 1976;294:687-90.

3 Weinstein L, Swartz MN. Pathogenic properties of invading micro-organisms. In: Sodeman WA Jr, Sodeman WA, eds. Pathologic physiology: mechanisms of disease. Philadelphia: W B Saunders, 1974:457-72. 
cases in that unhappy country than in all the developing countries put together. Conversely, with inadequate water supplies, there will be a lot more deaths from intestinal infection.

Finally, I do not want to be preached to about tobacco. I never said that tobacco was any good or put it in the same category as asbestos. What I did say, and will say again, is that the provision of cheap asbestos cement pipes for water supplies and sewage disposal would make a greater contribution to the health of these countries than misguided do goodery.

\section{NOTICES}

World Conference on Human Health and Chemical Accidents, Utrecht, 10-13 June 1991

In line with the recommendations of the World Conference on Chemical Accidents held in Rome, 7-10 July 1987, and the European Conference on Environment and Health held in Frankfurt, 7-8 December 1989, it was decided that it would be appropriate to organise a conference on chemical accidents, which will focus on the role of health professionals and other health authorities in preparation for, response to, and prevention of chemical accidents. This conference will be jointly organised by WHO Regional Office for Europe, OECD, UNEP, and IPCS.

For further details please contact: World Conference on Human Health and Chemical Accidents Secretariat, CEP Consultants Ltd, 26-28 Albany Street, Edinburgh EH1 3QH.

Eighth International Conference on Occupational Lung Diseases, Prague, Czechoslovakia, 14-17 September 1992

The International Labour Office intends to convene an International Conference on Occupational Lung Diseases in Prague, Czechoslovakia, from 14 to 17 September 1992, in cooperation with the Federal Ministry of Labour and Social Affairs of the
Czech and Slovak Federal Republic and the Czechoslovak Medical Society JE Purkyne. International Pneumoconioses Conferences have been held in Johannesburg (1930), Geneva (1938), Sydney (1950), Bucharest (1971), Caracas (1978), Bochum (1983) and Pittsburgh (1988). At the 7th Conference in Pittsburgh, which was attended by more than 1,000 participants, it was observed that occupational lung diseases other than pneumoconioses present an increasing burden on the health of workers in many activities. The ILO has therefore modified the title of the next Conference so as to cover the broad spectrum of work-related respiratory diseases. This 8th Conference on occupational lung diseases will provide a forum for the exchange of scientific and technical information on the health effects of air pollutants at the workplace on the respiratory system of exposed workers and on the prevention and control of occupational lung diseases. The major themes will be sources of air pollution and respiratory disorders at the workplace; risk evaluation by environmental monitoring and assessment of the exposure of workers; surveillance of the health of the workers; aetiopathogenesis, differential diagnosis and treatment of occupational respiratory diseases; and preventive and control measures at the workplace.

For further details please contact: 8th International Conference on Occupational Lung Diseases, Secretariat, c/o Czechoslovak Medical Society, PO Box 88, Sokolska 31, 12026 Prague 2, Czechoslovakia.

\section{University of California \\ Department of Medicine}

Postgraduate Programmes.

Occupational and Environmental Medicine Sessions I and III, San Francisco, 28th January-8 February 1991(Session I); 11-15 February 1991 (Session III).

Sponsored by Division of Occupational and Environmental Medicine, Department of Medicine, University of California.

Eighty hours category AMA and AAFP credits for Session I and 40 hours for Session III. Fees: $\$ 1200$ for physicians, Session I; $\$ 600$ for physicians, Session III. Contact Postgraduate Programs, 521 Parnassus Avenue, C-405, San Franciso, CA 94143-0656.

\section{Corrections}

Mortality of a cohort of tin miners 1941-86 (1990;47:665-76). For heading, table 5 "... time from first exposure" should read ". . . cumulative time underground".

In table 12 , 2nd row, 6 th column " $31 \%$ (15)" should read " $31 \%$ (5)".

On page 671 , the sentence above STOMACH CANCER should end "... arsenic exposure there was a significant excess of deaths from stomach cancer $(p=0.02)$ ".

On page 672 , section headed SILICOSIS line 8 , " $17 \%$ " should read "35\%". 